\title{
The role of the church in the struggle against poverty: A Hervormde Kerk in Suidelike Afrika per- spective
}

S P Mpanza

Khayelitsha

\begin{abstract}
The essence of being a church is love. The church as an organization based on love has the responsibility of loving God, his people and the world which God himself loved first. This paper is about the responsibility of a 'poor church', the Hervormde Kerk in Suidelike Afrika, which despite its poverty still has the vocation of becoming meaningful to its members. Two appeals are made here: firstly, that both the rich and the poor churches should, despite their circumstances, play their roles in combating poverty among their members. Secondly, churches should shift from charity work to development.
\end{abstract}

\section{Ekserp}

Die rol van die kerk in die stryd teen armoede: 'n Perspektief vanuit die Hervormde Kerk in Suidelike Afrika

Die essensie van kerkwees is liefde. Die kerk as 'organisme', gebaseer op liefde, het die verantwoordelikheid om God lief te hê en sy volk wat Hy eerste liefgehad het. Die artikel fokus op die verantwoordelikheid van ' $n$ arm kerk', die Hervormde Kerk in Suidelike Afrika, wat ten spyte van armoede steeds die roeping het om sin toe te voeg tot die lewe van lidmate. Twee oproepe word gemaak: ryk sowel as arm kerke moet die teenwoordigheid van armoede in eie kring bestry; kerke moet toesien dat die klem verskuif vanaf barmhartigheidsbetoning na ontwikkeling.

\section{INTRODUCTION}

When one is requested to deliver a paper on a topic like this, the first question that arises is the definition of a church. Knowing what a church is will make $u$ restling with this topic, and thereby determining whether the struggle against poverty is part of its

* A paper presented at the symposium of the Council of Ecumenical Affairs of the Nederduitsch Hervormde Kerk van Afrika and the Hervormde Kerk in Suidelike Afrika, 22 September 1995. 
mission or not, much easier. We are gathered here as members of different churches who, I suppose, confess to be members of the one catholic church instituted by the Lord Jesus Christ. But it is true that if we were to be asked to define church, each one of us would probably give a different definition. It, therefore, makes me not shy to give my own definition of what I understand by church.

\section{THE DEFINITION AND FUNCTIONS OF THE CHURCH}

The essence of being church is love. Out of love God sent his only begotten Son (Jn 3:16); out of love the apostles were able to work in difficult times among different people; and out of love the church was born. For Christians, therefore, love is like a cement mortar that keeps the bricks together, without which the house cannot stand. This illustration is self-explanatory.

What really needs to be tackled here is the function of the church in relation to poverty. Of course, to arrive at that relation we need to consult the Scriptures. In Mark 3:13-15 we find the following words:

Then Jesus went up a hill and called to himself the men he wanted. They came to him and he chose twelve, whom he named apostles. 'I have chosen you to be with me', he told them 'I will also send you out to preach, and you will have authority to drive out demons'.

From these three verses emanate three points necessary for a clear understanding of what the function of the church is:

* Firstly, there is an initiative from one side - God (Jesus) calls. Therefore the church is called to a personal relationship with God.

* Secondly, around Jesus exists a new society - the twelve - the symbol of the whole nation of God. Therefore being church demands an interpersonal relationship among fellow members (koinonia).

* Finally, this new society is directed to the world to preach and cast out demons. Therefore the church is called to a salvatory relationship with regard to the world (diakonia).

If one looks closely at these three dimensions of being a church, one will immediately recognise that all three have the connotation of service: service to God, service to fel- 
low Christians and service to the world. These three major functions should be performed by the church inseparably.

I agree with Peter Wagner (1984:180) that, while these functions are all important, they need to be prioritised. There is nothing that can substitute the relationship with God in Jesus Christ as the most important aspect in Christian life. Donald McGavran (1988) once pointed out that 'you cannot have the brotherhood of man without the fatherhood of God'. Without being committed to Christ first, the type of fellowship people may enjoy cannot be of the church but of what Dean Kelly (1986) calls a 'social club'. In church people gather together because they believe in Jesus Christ, and in his name they can think of mutual assistance and world service. The church, therefore, can be defined as: the coming together of people who believe in Jesus Christ to worship him, and in his name be of mutual assistance and undertake service to the world.

The Anglican Archbishop of Cape Town, Desmond Tutu (1983), once argued that 'the church exists primarily to worship and adore God. It must praise his holy name. But it can never use this as a form of escapism. Precisely because it worships such a God, it must take seriously the world he has created and which he loves so much that he gave his only begotten Son for it' (Tutu 1983:84).

This is what I understand to be the essence and the function of the church. If you share this view, then our understandings of the church concur.

\section{CHURCH'S STRUGGLE AGAINST POVERTY}

However, I am asked to speak about the role of the church in the struggle against poverty. I therefore would like to start by mentioning that there are two ways in which one can deal with this concern. There is, on the one hand, the so-called 'church for the poor' (i e the church which is itself poor) and on the other hand, the so-called 'church of the poor' ( $\mathrm{i}$ e the church that has undertaken to help the poor). I will talk about these two types of churches as one, simply because I am standing here representing one of the poorest churches in South Africa which nevertheless, still needs to be meaningful to its poor members.

Many people in South Africa show signs of having lost the meaning of life. As a result, some have to an extent gone back to their forefathers' religions. An investigation into this behaviour indicates that, among others, poverty is cited as a reason, and perhaps the major reason.

The majority of Black churches in South Africa are poor. But this should not be used as a form of escapism, as a reason for not becoming 'the church for the poor'. Although the Black churches might not have enough resources to help the other people in the world, I believe that they can still be 'the church for the poor' within their own communities. And since charity begins at home, members can mutually help one another. 


\subsection{WHAT IS POVERTY?}

Mrs Witbooi from the Karoo once described poverty as 'not knowing where your next meal is going to come from, and always wondering when the council is going to put your furniture out, and always praying that your husband must not lose his job. To me, this is poverty' (Ramphele \& Wilson 1991:14). Indeed, poverty has many faces and is experienced in different ways by different people at different times. In a nutshell my own definition of poverty is deficiency of minimal essentials of life.

Some of us at this conference, in response to the needs of the poor in our congregations, may either say: 'we have done nothing because we are also poor', or 'we have just started accumulating funds for charity work'. By charity or relief work in this paper I mean something given to people in response to particular suffering or a particular need. In many reports of my own church, I have realised that many congregations are struggling to do even charity work. Some congregations have for many years been involved in charity projects, sometimes through the assistance of the Nederduitsch Hervormde Kerk van Afrika (NHKA). While this is something good and laudable, it is unfortunately the kind of relief work that has indirectly made the poor complacent with their social state of poverty. They tend to live under the assumption that whenever they ask somebody will provide. Of course, for people who know no better life, it is to easy to accept their state of poverty, especially if they get occasional doses of charity.

\section{A PLEA FOR A PARADIGM SHIFT: FROM CHARITY TO DEVELOP- MENT}

We are reminded of the lame man who used to sit at the Beautiful Gate of the Temple. This story is in Acts 3:1ff. Verse $2 b$ reads as follows: 'Everyday he was carried to the gate to beg for money from the people who were going into the Temple'. Possibly the gifts he always received made him forget that he was disabled and caused him to enjoy the life of receiving alms. I strongly suspect that on the day he got nothing until sunset he remembered and perhaps wished that he could be saved from his handicapped state. It is possible that there were those who enjoyed seeing him always begging and enjoyed being donors of alms. But when Peter and John, two of the twelve apostles, came to the lame man he as usual expected something but they wished him something beyond just charity. After telling him to stand up in the name of Jesus Christ of Nazareth, verse 7 reads 'Peter took him by his right hand and helped him up'. That is empowerment and no longer charity. Lifting people up so that they can help themselves is what the church should do for the poor. What people need is development and empowerment and not just relief work. 
By development and empowerment I mean a sustainable improvement of the living conditions of humanity. It aims at transforming the socio-economic situation of the people. The church as a grass roots organization can serve as a very useful instrument for societal transformation. The Hervormde Kerk in Suidelike Afrika must therefore take a step further by considering initiating development projects and programmes, since these are among the priorities of the church. That should help people restore the lost meaning of life.

\section{HERVORMDE KERK IN SUIDELIKE AFRIKA AS 'THE POOR CHURCH'}

Ministers of the Hervormde Kerk in Suidelike Afrika are preaching the Word of God predominantly to the poor. They cannot bear to always tell the poor to go in peace and yet turn their backs on their material needs, as if they were only spiritual beings. Unfortunately, the undoing of the ministers is that they are not fully equipped to work among poor people. Perhaps the Hervormde Teologiese Opleiding should be challenged to consider this very seriously.

The church should stage a concerted fight against poverty using all the weaponry it has. This is where the Reconstruction and Development Programme (RDP) comes in. RDP does not mean a packet of goodies to be delivered to people for a better life. It is not someting to be delivered by someone from elsewhere, but it is something to be done by people from within the communities to develop themselves. The policy of the governmeni is to provide funds to assist those communities which are doing something to combat poverty. This, therefore, challenges the church to be proactive in these communities as an instrument against poverty.

I hereby mean that it is the role of the church not only to preach in word but also in deed, so as to wholly develop and empower its people. I will keep on repeating that programmes and projects must aim at transforming people and getting them out of a syndrome of dependence towards self-reliance. That is empowerment.

In our congregations we have people who have the 'know-how' and the skills of developing other people but they are given no chance. Some outside the church are deeply involved in development projects because of their skills, but congregations do not give them a chance. They deliberately turn them into their frozen assets. If those congregations do not use such people they will continue losing them to the world which will use them and consequently assimilate them. Some congregations have members who are leaders of the so-called Masingcwabane. These are sometimes the large burial societies in the Black townships. In some places we have the socalled Umholiswano (Zulu) or Umgalelo (Xhosa) which are all attempts by poor Black people to empower themselves. May I ask, should the church not start capitalising on what people already know about development? 
Some churches already have infrastructure, which some organizations do not have. They have sites, running water, church buildings, electricity, et cetera. This should be used for the development and empowerment of the people. If possible, churches should develop structures to deal with the problem of poverty. It is a problem that needs urgent attention.

The Nederduitsch Hervormde Kerk van Afrika (NHKA), as the mother church of the Hervormde Kerk in Suidelike Afrika and as the church that can, at least, make ends meet, should also play an important role in assisting the Hervormde Kerk in Suidelike Afrika towards seeing that this vision is realised.

\section{THREE STEPS TOWARDS DEVELOPMENT}

May I mention three things which, I think, are of the utmost importance if we want to see development become a reality in our congregations:

* Firstly, let the poor identify their priority needs. Usually people who easily recognise the necessity for change are the people who are working among the poor, but from an advantaged position. There is a misconception that the advantaged know the priority needs of the poor more than the poor themselves. This is indeed a mistake. Rather, I would suggest that the poor be allowed to identify their needs on their own.

* Secondly, any person or committee given the task of developing people should take their capabilities into consideration. I have already mentioned above that deveiopment should not necessarily be something from outside or from top to bottom, but should be done by the poor themselves. They themselves feel the thorn. It is, therefore, important to look at their resources and at what they can afford. For example, some congregations have infrastructure while others don't.

* Thirdly, involve the poor in decision-making. There is a very bad tendency of thinking that because people are poor, someone has to take decisions on their behalf. That practice always meets with a great deal of resistance at the end of the day. The poor understand their situation best.

Another advantage of this is that, when people participate, it is easier to find their hidden talents than when keeping them passive. By invoiving the poor, one is assisting in 
restoring their dignity and selfesteem. This is also a challenge to our church structures where every key position is occupied by a minister.

\section{CONCLUSION}

In conclusion, I wish to summarise all that I have said in five points:

1. Poverty is depressing and dehumanizing. The church should share the Good News with the poor. The proclamation of the Good News should bring hope, the hope of life without poverty.

2. The church should assist in sustainable production of food. It is not enough to preach the Good News. The church should empower the poor so as to enable them to produce their own food consistently.

3. The church should advocate sharing. Those who have, should be willing to share with those who do not, not only in a charitable fashion, but also in a way which will lead to self-reliance. That will forge development.

4. Theological training should incorporate dimensions of empowerment in the curriculum. Ministers (especially, Black) cannot run away from the truth that they are preaching to the poor. They need to be well equipped for this.

5. Finally, the church should help in creating an enabling environment for the poor. Let all the churches and their congregations scattered all over the country serve as the source of hope and centre of empowerment.

Christianity as a religion should strive to give meaning and identity to poor people who have lost their identity because of poverty.

\section{Works consulted}

Wagner, C P 1984. Your Church Can Grow. Glendale.

Kelly, D M 1986. Why Conservative Churches Are Growing? New York: A Mercer University Press.

McGavran, D A 1988. Understanding Church Growth. Grand Rapids.

Ramphele, M \& Wilson, F, 1989. Uprooting Poverty.

Tutu, D 1983. Hope and Suffering. Grand Rapids. 